\title{
Apical stem cells sustaining prosperous evolution of land plants
}

\author{
Ryuichi Nishihama ${ }^{1} \cdot$ Satoshi Naramoto ${ }^{2,3}$
}

Published online: 28 April 2020

(C) The Botanical Society of Japan 2020

Ever since plants colonized the terrestrial environment ca. 470 million years ago, they have evolved to maximize the efficiency for the use of above-ground and underground spaces by coping with harsh environmental stresses on land, including drought, high salinity, and UV. Innovation of the shooting and rooting systems contributed greatly. For instance, shoots form leaves radially around a stem to achieve efficient light absorption, thicken their stems to increase body mass, and branch out new shoots to produce more descendants. Roots are comprised of centrifugally layered tissues and branch by forming lateral roots. These developmental patterns are based on the three-dimensional (3D) growth axes, namely the apical-basal and radial axes. One major evolutionary basis that enabled these inventions is the emergence of stem cells capable of dividing with multiple planes in a regulated fashion and the increase of stem cell numbers in the apex, i.e. single apical cells in bryophytes, one or two apical cells in lycophytes and ferns, and multiple stem cells in seed plants (Harrison 2017). This apical stem cell-based growth mode allowed the drastic expansion of diversity in land plants.

In the green lineage, the stem cell system was acquired in charophyte green algae. Stem cells in charophytes divide only in one or two directions and thereby can only direct up to $2 \mathrm{D}$ body plans, such as filaments, branching filaments and mats. Bryophytes, consisting of liverworts, mosses, and hornworts, are basal land plant lineages that diverged from charophytes and have 3D body plans, as clearly manifested by rotational leaf formation patterns in liverwort and moss

Ryuichi Nishihama

nishihama@lif.kyoto-u.ac.jp

1 Graduate School of Biostudies, Kyoto University, Kyoto 606-8502, Japan

2 Graduate School of Life Sciences, Tohoku University, Sendai 980-8577, Japan

3 Present Address: Department of Biological Sciences, Faculty of Science, Hokkaido University, Hokkaido 060-0810, Japan species. Thus, coinciding with land colonization, a third dimension in the division plane of stem cells was acquired and paved the way for drastic morphological innovations.

Recent studies identified moss genes involved in the 3D regulation of stem cell's division. The moss Physcomitrella patens protonemata grow as filamentous tissues with a single apical stem cell, that is $1 \mathrm{D}$ growth. Occasionally, new stem cells branch (2D growth) and divide obliquely to initiate formation of gametophores, or 3D leafy shoots. This transition from 2 to $3 \mathrm{D}$ growth was shown to be regulated by the APETALA2-type transcription factors APBs (for AINTEGUMENTA, PLETHORA, and BABY BOOM; Aoyama et al. 2012). The oblique division is defective in mutants for Defective Kernel 1 (DEK1; Perroud et al. 2014), NO GAMETOPHORES 1 (NOG1; Moody et al. 2018), and genes in the CLAVATA (CLV) signaling pathway (Whitewoods et al. 2018). The CLV pathway in angiosperms is well known for the regulation of the maintenance of stem cell pools in concert with the homeobox transcription factor WUSCHEL (WUS), a key regulator of stem cell fate (see below for WUS). Whitewoods et al. (2018) demonstrated that the CLV pathway regulates cell division planes also in the angiosperm Arabidopsis thaliana. As not only moss but also liverwort and hornwort species lack an orthologous gene for WUS (Bowman et al. 2017; Li et al. 2020; Sakakibara et al. 2014; Zhang et al. 2020), it is reasonable to assume that the CLV cell-communication system was originally invented to control 3D growth and then co-opted to control stem cell population by recruiting WUS. This example readily shows that it is of great significance to argue the evolution of stem cells in land plants by comparing their characteristics and functions, or mechanisms of their establishment and maintenance, in divergent taxonomical groups. This JPR symposium titled "Apical stem cell(s): evolutionary basis for 3D body plans in land plants" presents review and original articles regarding stem cell biology along land plant evolution. 
The first three papers are review articles. In the first review, Moody (2020) describes comprehensively the morphologies of early streptophytes, from charophyte green algae to bryophytes, with nice illustrations and summarizes the evolution of their morphological complexities to discuss how it relates to the dimensions of stem cell division planes. This serves as a good introductory article for the traits and taxonomies of these green lineage species, with which readers can follow the evolutionary transition from 1D through $2 \mathrm{D}$ to $3 \mathrm{D}$ growth. The author also points out convergent evolution of 3D apical growth between land plants and brown algae, which are independently evolved lineages and may share similar principles.

Roots are thought to have evolved multiple times independently in vascular plants (Friedman et al. 2004; Kenrick and Crane 1997; Raven and Edwards 2001), and how root apical meristems (RAMs) evolved is an open question. Seed plant roots generally contain the quiescent center (QC), an organizer to maintain the root stem cell niche. In the second review article, Fujinami et al. (2020) classify RAM organizations in lycophytes into four types based on cell division activity and anatomy. The authors previously reported the existence of a QC-like area with low division activity in the root of a lycophyte species, but the absence of such areas in other lycophyte species (Fujinami et al. 2017). Together with the fact that lycophyte roots branch dichotomously, the data support the previous hypothesis of convergent evolution of roots in the vascular plant lineage and opens new questions on its molecular basis.

The shoot apical meristem (SAM) of A. thaliana consists of clonally distinct cell layers, that is L1, L2, and L3 from the outside, in all of which stem cells are embedded at the center. The number of stem cells is tightly regulated by their interaction with the organizing center (OC) located in the L3 layer. This non-cell autonomous control of stem cells is mediated by a negative feedback loop involving the CLV signaling pathway and the homeobox transcription factor WUS (Gaillochet et al. 2017). WUS mRNAs accumulate exclusively in the $\mathrm{OC}$, but the proteins are detected in the L1 and L2 stem cells (Daum et al. 2014; Yadav et al. 2011), indicating cell-to-cell movement of WUS proteins. In the third review article, Fuchs and Lohmann (2020) comprehensively review previous studies on the WUS-mediated noncell autonomous control of stem cells. A special emphasis is put on the mechanisms of cell-to-cell protein motility with detailed structural considerations and the function of WUS transcription factor.

It is known that position-dependent cell-fate determination underlies organ formation and tissue differentiation in angiosperms (Scheres 2001). In contrast, mosses and leafy liverworts were reported to form each leaf within a merophyte, a clonal group of cells derived from a daughter cell of the single apical cell (Crandall-Stotler 1980; Harrison et al.
2009), indicating cell-lineage-based organ development in these taxa of bryophytes. In this issue, Suzuki et al. (2020) apply a clonal analysis technique to a thalloid liverwort, Marchantia polymorpha, and elucidate that organs formed on the dorsal surface of the thallus contain cells derived from multiple merophytes. Thus, the positional cue-directed organ formation is likely to be a common theme in land plants associated with the 3D mode of apical cell division.

Gametophytes in bryophytes and sporophytes in angiosperms develop analogous apical meristems whose activities are regulated by apical stem cells (Prigge and Bezanilla 2010). Arabidopsis LIGHT-DEPENDENT SHORT HYPOCOTYLS1 and the Oryza G1 (ALOG) protein family regulates apical meristem activities and lateral organ development in angiosperms (MacAlister et al. 2012; Takeda et al. 2011; Yoshida et al. 2009, 2013). Recent findings identified that the ALOG protein family regulates meristem maintenance and lateral organ development in M. polymorpha (Naramoto et al. 2019). This suggests that common regulatory mechanisms mediated by ALOG control apical meristem activities, such as cell proliferation and lateral organ formation in land plants despite their independent origins (Naramoto et al. 2019). In this issue, Naramoto et al. (2020) perform phylogenetic analysis of ALOG family proteins and identify that the ALOG protein family emerged before the evolution of land plants and that their molecular functions have been conserved at least in some part during the evolution of land plants. These findings imply that the ALOG gene had acted as an ancient mechanism controlling apical meristem activities in common ancestors of land plants, which subsequently recruited different regulatory mechanisms between bryophytes and angiosperms.

Stem cell maintenance and position-dependent cell differentiation are regulated by various means, including phytohormone signaling, cell-to-cell movement of proteins, and peptide-ligand signaling. Together with the moss CLV pathway function in the regulation of stem cell division planes, a recent finding that CLE (CLAVATA3/EMBRYO SURROUNDING REGION-related) peptide signaling regulates meristem activity in the liverwort (Hirakawa et al. 2019) suggests the acquisition of cell-cell communication systems via peptide ligands contributed greatly to 3D growth of land plants. In this issue, Cammarata and Scanlon (2020) focus on such systems regulating stem cells and report phylogenetic relationships of LEUCINE-RICH REPEATRECEPTOR LIKE KINASEs (LRR-RLKs) and related proteins across diverse land plant models. Their analysis finds structural evolution of some protein families and shows that several stem cell-regulating protein clades share origins with immune signaling proteins, providing new insights into the broader aspect of stem cell regulations.

We still do not know much about how stem cells can be defined in terms of gene expression, epigenetic status, 
chromatin structure, and division plane control. State-of-art technologies, such as single-cell analysis (e.g., Denyer et al. 2019; Jean-Baptiste et al. 2019; Ryu et al. 2019; Zhang et al. 2019), as well as comparative studies with a wide range of plant species (e.g., Frank et al. 2015; Frank and Scanlon 2015), will resolve these questions.

\section{References}

Aoyama T, Hiwatashi Y, Shigyo M, Kofuji R, Kubo M, Ito M, Hasebe M (2012) AP2-type transcription factors determine stem cell identity in the moss Physcomitrella patens. Development 139:3120-3129

Bowman JL, Kohchi T, Yamato KT, Jenkins J, Shu S, Ishizaki K, Yamaoka S, Nishihama R, Nakamura Y, Berger F, Adam C, Aki SS, Althoff F, Araki T, Arteaga-Vazquez MA, Balasubrmanian S, Barry K, Bauer D, Boehm CR, Briginshaw L,Caballero-Perez J, Catarino B, Chen F, Chiyoda S, Chovatia M, Davies KM, Delmans M, Demura T, Dierschke T, Dolan L, Dorantes-Acosta AE, Eklund DM, Florent SN, Flores-Sandoval E, Fujiyama A, Fukuzawa H, Galik B, Grimanelli D, Grimwood J, Grossniklaus U, Hamada T, Haseloff J, Hetherington AJ, Higo A, Hirakawa Y, Hundley HN, Ikeda Y, Inoue K, Inoue SI, Ishida S, Jia Q, Kakita M, Kanazawa T, Kawai Y, Kawashima T, Kennedy M, Kinose K, Kinoshita T, Kohara Y, Koide E, Komatsu K, Kopischke S, Kubo M, Kyozuka J, Lagercrantz U, Lin SS, Lindquist E, Lipzen AM, Lu CW, De Luna E, Martienssen RA, Minamino N, Mizutani M, Mizutani M, Mochizuki N, Monte I, Mosher R, Nagasaki H, Nakagami H, Naramoto S, Nishitani K, Ohtani M, Okamoto T, Okumura M, Phillips J, Pollak B, Reinders A, Rovekamp M, Sano R, Sawa S, Schmid MW, Shirakawa M, Solano R, Spunde A, Suetsugu N, Sugano S, Sugiyama A, Sun R, Suzuki Y, Takenaka M, Takezawa D, Tomogane H, Tsuzuki M, Ueda T, Umeda M, Ward JM, Watanabe Y, Yazaki K, Yokoyama R, Yoshitake Y, Yotsui I, Zachgo S, Schmutz J (2017) Insights into land plant evolution garnered from the Marchantia polymorpha genome. Cell 171:287-304

Cammarata J, Scanlon MJ (2020) A functionally informed evolutionary framework for the study of LRR-RLKs during stem cell maintenance. J Plant Res. https://doi.org/10.1007/s10265-020-01197-w

Crandall-Stotler B (1980) Morphogenetic designs and a theory of bryophyte origins and divergence. Bioscience 30:580-585

Daum G, Medzihradszky A, Suzaki T, Lohmann JU (2014) A mechanistic framework for noncell autonomous stem cell induction in Arabidopsis. Proc Natl Acad Sci USA 111:14619-14624

Denyer T, Ma X, Klesen S, Scacchi E, Nieselt K, Timmermans MCP (2019) Spatiotemporal developmental trajectories in the Arabidopsis root revealed using high-throughput single-cell RNA sequencing. Dev Cell 48:840-852

Frank MH, Scanlon MJ (2015) Transcriptomic evidence for the evolution of shoot meristem function in sporophyte-dominant land plants through concerted selection of ancestral gametophytic and sporophytic genetic programs. Mol Biol Evol 32:355-367

Frank MH, Edwards MB, Schultz ER, McKain MR, Fei Z, Sorensen I, Rose JK, Scanlon MJ (2015) Dissecting the molecular signatures of apical cell-type shoot meristems from two ancient land plant lineages. New Phytol 207:893-904

Friedman WE, Moore RC, Purugganan MD (2004) The evolution of plant development. Am J Bot 91:1726-1741
Fuchs M, Lohmann JU (2020) Aiming for the top: non-cell autonomous control of shoot stem cells in Arabidopsis. J Plant Res. https://doi. org/10.1007/s10265-020-01174-3

Fujinami R, Yamada T, Nakajima A, Takagi S, Idogawa A, Kawakami E, Tsutsumi M, Imaichi R (2017) Root apical meristem diversity in extant lycophytes and implications for root organs. New Phytol 215:1210-1220

Fujinami R, Yamada T, Imaichi R (2020) Root apical meristem diversity and the origin of roots: insights from extant lycophytes. J Plant Res. https://doi.org/10.1007/s10265-020-01167-2

Gaillochet C, Stiehl T, Wenzl C, Ripoll JJ, Bailey-Steinitz LJ, Li L, Pfeiffer A, Miotk A, Hakenjos JP, Forner J, Yanofsky MF, Marciniak-Czochra A, Lohmann JU (2017) Control of plant cell fate transitions by transcriptional and hormonal signals. eLife 6:e30135

Harrison CJ (2017) Development and genetics in the evolution of land plant body plans. Philos Trans R Soc B 372:20150490

Harrison CJ, Roeder AH, Meyerowitz EM, Langdale JA (2009) Local cues and asymmetric cell divisions underpin body plan transitions in the moss Physcomitrella patens. Curr Biol 19:461-471

Hirakawa Y, Uchida N, Yamaguchi YL, Tabata R, Ishida S, Ishizaki K, Nishihama R, Kohchi T, Sawa S, Bowman JL (2019) Control of proliferation in the haploid meristem by CLE peptide signaling in Marchantia polymorpha. PLoS Genet 15:e1007997

Jean-Baptiste K, McFaline-Figueroa JL, Alexandre CM, Dorrity MW, Saunders L, Bubb KL, Trapnell C, Fields S, Queitsch C, Cuperus JT (2019) Dynamics of gene expression in single root cells of Arabidopsisthaliana. Plant Cell 31:993-1011

Kenrick P, Crane PR (1997) The origin and early diversification of land plants. Smithsonian Institution Press, Washington

Li FW, Nishiyama T, Waller M, Frangedakis E, Keller J, Li Z, Fernandez-Pozo N, Barker MS, Bennett T, Blazquez MA, Cheng S, Cuming AC, de Vries J, de Vries S, Delaux PM, Diop IS, Harrison CJ, Hauser D, Hernandez-Garcia J, Kirbis A, Meeks JC, Monte I, Mutte SK, Neubauer A, Quandt D, Robison T, Shimamura M, Rensing SA, Villarreal JC, Weijers D, Wicke S, Wong GK, Sakakibara K, Szovenyi P (2020) Anthoceros genomes illuminate the origin of land plants and the unique biology of hornworts. Nat Plants 6:259-272

MacAlister CA, Park SJ, Jiang K, Marcel F, Bendahmane A, Izkovich Y, Eshed Y, Lippman ZB (2012) Synchronization of the flowering transition by the tomato TERMINATING FLOWER gene. Nat Genet 44:1393-1398

Moody LA (2020) Three-dimensional growth: a developmental innovation that facilitated plant terrestrialization. J Plant Res. https://doi. org/10.1007/s10265-020-01173-4

Moody LA, Kelly S, Rabbinowitsch E, Langdale JA (2018) Genetic regulation of the $2 \mathrm{D}$ to $3 \mathrm{D}$ growth transition in the moss Physcomitrella patens. Curr Biol 28:473-478

Naramoto S, Jones VAS, Trozzi N, Sato M, Toyooka K, Shimamura M, Ishida S, Nishitani K, Ishizaki K, Nishihama R, Kohchi T, Dolan L, Kyozuka J (2019) A conserved regulatory mechanism mediates the convergent evolution of plant shoot lateral organs. PLoS Biol 17:e3000560

Naramoto S, Hata Y, Kyozuka J (2020) The origin and evolution of the ALOG proteins, members of a plant-specific transcription factor family, in land plants. J Plant Res. https://doi.org/10.1007/s1026 5-020-01171-6

Perroud PF, Demko V, Johansen W, Wilson RC, Olsen OA, Quatrano RS (2014) Defective Kernel 1 (DEK1) is required for three-dimensional growth in Physcomitrella patens. New Phytol 203:794-804

Prigge MJ, Bezanilla M (2010) Evolutionary crossroads in developmental biology: Physcomitrella patens. Development 137:3535-3543

Raven JA, Edwards D (2001) Roots: evolutionary origins and biogeochemical significance. J Exp Bot 52:381-401 
Ryu KH, Huang L, Kang HM, Schiefelbein J (2019) Single-cell RNA sequencing resolves molecular relationships among individual plant cells. Plant Physiol 179:1444-1456

Sakakibara K, Reisewitz P, Aoyama T, Friedrich T, Ando S, Sato Y, Tamada Y, Nishiyama T, Hiwatashi Y, Kurata T, Ishikawa M, Deguchi H, Rensing SA, Werr W, Murata T, Hasebe M, Laux T (2014) WOX13-like genes are required for reprogramming of leaf and protoplast cells into stem cells in the moss Physcomitrella patens. Development 141:1660-1670

Scheres B (2001) Plant cell identity. The role of position and lineage. Plant Physiol 125:112-114

Suzuki H, Harrison CJ, Shimamura M, Kohchi T, Nishihama R (2020) Positional cues regulate dorsal organ formation in the liverwort Marchantia polymorpha. J Plant Res. https://doi.org/10.1007/ s10265-020-01180-5

Whitewoods CD, Cammarata J, Nemec Venza Z, Sang S, Crook AD, Aoyama T, Wang XY, Waller M, Kamisugi Y, Cuming AC, Szövényi P, Nimchuk ZL, Roeder AHK, Scanlon MJ, Harrison CJ (2018) CLAVATA was a genetic novelty for the morphological innovation of 3D growth in land plants. Curr Biol 28:2365-2376

Takeda S, Hanano K, Kariya A, Shimizu S, Zhao L, Matsui M, Tasaka M, Aida M (2011) CUP-SHAPED COTYLEDON1 transcription factor activates the expression of LSH4 and LSH3, two members of the ALOG gene family, in shoot organ boundary cells. Plant J 66:1066-1077

Yadav RK, Perales M, Gruel J, Girke T, Jönsson H, Reddy GV (2011) WUSCHEL protein movement mediates stem cell homeostasis in the Arabidopsis shoot apex. Genes Dev 25:2025-2030
Yoshida A, Suzaki T, Tanaka W, Hirano H (2009) The homeotic gene long sterile lemma (G1) specifies sterile lemma identity in the rice spikelet. Proc Natl Acad Sci USA 106:20103-20108

Yoshida A, Sasao M, Yasuno N, Takagi K, Daimon Y, Chen R, Yamazaki R, Tokunaga H, Kitaguchi Y, Sato Y, Nagamura Y, Ushijima T, Kumamaru T, Iida S, Maekawa M, Kyozuka J (2013) TAWAWA1, a regulator of rice inflorescence architecture, functions through the suppression of meristem phase transition. Proc Natl Acad Sci USA 110:767-772

Zhang TQ, Xu ZG, Shang GD, Wang JW (2019) A single-cell RNA sequencing profiles the developmental landscape of Arabidopsis root. Mol Plant 12:648-660

Zhang J, Fu XX, Li RQ, Zhao X, Liu Y, Li MH, Zwaenepoel A, Ma H, Goffinet B, Guan YL, Xue JY, Liao YY, Wang QF, Wang QH, Wang JY, Zhang GQ, Wang ZW, Jia Y, Wang MZ, Dong SS, Yang JF, Jiao YN, Guo YL, Kong HZ, Lu AM, Yang HM, Zhang SZ, Van de Peer Y, Liu ZJ, Chen ZD (2020) The hornwort genome and early land plant evolution. Nat Plants 6:107-118

Publisher's Note Springer Nature remains neutral with regard to jurisdictional claims in published maps and institutional affiliations. 